Advances in Geosciences, 7, 223-229, 2006

SRef-ID: 1680-7359/adgeo/2006-7-223

European Geosciences Union

(c) 2006 Author(s). This work is licensed

under a Creative Commons License.

\title{
Socio-economic impacts of major floods in Italy from 1951 to 2003
}

\author{
B. Lastoria, M. R. Simonetti, M. Casaioli, S. Mariani, and G. Monacelli \\ Agency for Environmental Protection and Technical Services (APAT), Rome, Italy \\ Received: 7 October 2005 - Revised: 25 January 2006 - Accepted: 1 February 2006 - Published: 10 March 2006
}

\begin{abstract}
Meteorological and hydrological monitoring and modeling, with particular regard for extreme hydrological events, represent important activities carried out by the Hydrological and Inland Waters Service of the Italian Agency for Environmental Protection and Technical Services (APAT).

Recently, a study on the socio-economic effects of floods was published in the Italian Environmental Data Yearbook by APAT. It is based on processed data related to the major floods (i.e., events with at least a casualty or that have generated economic damages higher than $0.001 \%$ of the Gross Domestic Product) striking Italy between 1951 and 2003. Information was gathered from technical reports and/or databases belonging to APAT, Italian Regional Environmental Agencies (ARPAs), central and local authorities, research institutions and newspaper reports. These data are collected in tables reporting the number of flood events and of casualties and the amount of financial resources required for environmental restoration and/or for risk mitigation purposes.
\end{abstract}

For year 2003, when APAT has begun a systematic monitoring of flood events in Italy, data concerning rainfall, number of persons involved, evacuation and urgent measures introduced to face the event (laws and acts) are also included. In this way, it was possible to realize a new database, in which flood events that caused the declaration of the state of emergency have been collected. Because of the difficulties in finding sufficiently reliable data for the period before the II World War, the collection of historical data started from 1951. During this period, about $50 \%$ of the flood events examined have caused at least 5 victims each, and about $10 \%$ more than 100; these data highlight the considerable social impact of flood events and suggest the importance of creating an integrated database to collect information about flood events involving all Europe.

These two databases (the historical and updating archives) could be useful for taking into account the different anthropic

Correspondence to: B. Lastoria

(barbara.lastoria@apat.it) impacts during the time, the real effectiveness of protection measures already realized and could represent a valid reference for further interventions.

\section{Introduction}

A wider diffusion of information in the world has induced a deep cultural change in people's feelings towards environmental problems during these last years, developing an increasing consciousness of how delicate the balance between man and his territory is.

In the past, natural disasters were regarded as ineluctable events, but nowadays, thanks to the news divulgated by mass media and a higher available knowledge, people are less prone to consider inevitable the serious social and economic consequences of climatic extreme events. TV and newspapers reportages, showing terrific images of natural hazards occurred here and there on Earth, are fostering the idea that these devastating events are less rare now than before.

The modern approach towards natural disasters has shifted away from being hazard-oriented towards a risk-based approach. Thus while flood research and flood protection policy has been dominated for long time by a technical view, the social and socio-economic aspects gained in importance only recently with a shift from technical oriented flood protection towards flood risk management (Messner and Meyer, 2005).

Three factors can be considered significant for the definition of the risk concept: hazard, vulnerability, exposure. Hazard is the probability of occurrence within a specified period of time in a given area, of a potentially damaging event so it implies to consider the frequency and the magnitude of the threatening event. Vulnerability means the degree of loss to a given element at risk or set of such elements resulting from the occurrence of phenomenon of a given magnitude. It represents the attitude of an element to be damaged or destroyed. At last the exposure is the value of the elements at risk which means the population, buildings and 
civil engineering works, economic activities, public services, utilities, infrastructure and so on.

The Risk concept, as above defined, allows defining a practical conceptual frame for risk analysis, which is in fact "the process of quantification of the probabilities and expected consequences for identified risks" as mentioned by Plattner (2005).

A detailed understanding of what events have occurred in the past and their effects provides the basis for understanding what could or will happen in the future. In Italy, the principal flood event data sources is given by the hydro-meteorological network of monitoring stations, the Annali Idrologici (Hydrological Yearbook) and special publications edited in particular by the former National Hydrographic Service (now in the Italian Agency for Environmental Protection and Technical Services - APAT) when critical events occurred. These sources provide data for a statistical analysis of meteorological extreme events and they allow to determine the frequency (or the return period) and event magnitude, expressed by threshold values of rainfall intensity, hydrometric level or peak discharge.

Type and density of vegetation, soil type and land use are factors that influence the flood impact on soil in terms of both rate and volume of runoff expected from a watershed. Human actions on rivers, as on catchments, such as deforestation, straightening of rivers, subtraction of natural flood plains, urbanization, etc. cause change of flood frequencies. Moreover, land use changes, in particular when it means a major presence of people, economic activities and so on, especially on flood plains, may cause a variable risk level in time also in terms of vulnerability and exposure.

Traditionally, flood defence planning focused on safety standards, such as dike design levels or reservoir volumes, neglects the valuables protected by a defence system and, hence, the efficiency of flood protection measures (Messner and Meyer, 2005). It is evident that the advantage of flood protection in the form of prevented damages should be taken into account, this means that damages expected in case of measure failure need to be considered. In principle, no technical solution to flooding is absolutely safe or definitive; there is always a residual risk, also due to the territory modification or owing to the rare flood exceeding the design flood, since it is hardly possible to offer protection against any conceived flood (Plate, 2002).

Flood damages refer to a wide range of harmful effects on humans, public infrastructure, cultural heritage, ecological systems, industrial production and economy. Some of these damages can be specified in monetary terms, others are usually recorded by non-monetary measures like number of lives lost.

Risk management imply also the determination of the significance and acceptability of risks and so the level of risk that a society is able and willing to carry. The acceptability level of risk can vary considerably over time; for instance, it is much lower immediately after a hazard impact than immediately before it (Granger, 2000). In other words, the level of the risk acceptance is connected with the degree of memory of the events and thus with their occurrence frequency. Moreover, even when direct experience exists, it is often biased by the point of observation or by what has been reported by others (Delitala, 2005). The perception of disasters by public domain is not only determined by objective data, which can be, for example, the number of casualties or the value of damages due to an event, but also from the relevance that media give to it. This perception is central to the process of the resource allocation for the risk mitigation, and in general it influences somehow the type and entity of measures taken by authorities and people involved in flood risk management.

\section{Previous studies}

One of the most interesting and detailed work on soil impact, generated by landslides and floods in Italy, is a database of historical information known as the Italian National Research Council's Aree Vulnerate Italiane (AVI - Italian Damaged Urban Areas) archive (Guzzetti and Tonelli, 2004). The database was originally designed for responding to a request of the Italian Department of Civil Protection, and it was aimed at helping the regional assessment of landslide and flood risk in Italy. The database was compiled in 1991-1992 to cover the time period from 1917 to 1990 , and then updated to cover systematically the time period from 1917 to 2000 , and non-systematically time periods from 1900 to 1916 and from 2001 to 2002.

This census provides, for civil protection purposes, the territorial location of the hydrogeological disasters occurred in that period, what however does not represent a proper map of risk. Information is related to single municipalities or places hit and it is daily reported, showing that this census was not realized by events, being registered the same meteoric phenomenon, gone on for many days, so many times as the struck municipalities are. Moreover this storage has concerned all events surveyed by any source no matter its relevance.

Beginning in 1999, the Italian National Research Council has inserted the AVI project database together with other digital catalogues into a single information system on hydrologic and geomorphologic hazards and risk, also known as Sistema Informativo sulle Catastrofi Idrogeologiche (SICI - Information System on Hydrological and Geomorphological Catastrophes). SICI contains a collection of databases and digital catalogues concerning a variety of historical, geographical, and bibliographical information on landslides and floods in Italy. In particular, it contains information on damage caused by mass movements and inundations, daily discharge measurements and solid-transport measurements at selected gauging stations, bibliographical and reference information on landslides and inundations. A catalogue of the Italian legislation on hydrological and geological hazards and risk is also included. Databases are not merged into a single archive, thus they can be considered as different sources of information within a single information system (Guzzetti and Tonelli, 2004). 
Table 1. Example of data stored in the APAT historical archive. For each flood event, involved regions, time duration, casualties, and estimated economic total damage (both in Euros and in percentage with respect to GDP) are reported.

\begin{tabular}{|c|c|c|c|c|c|}
\hline Days & Month and year & Involved regions & $\begin{array}{l}\text { Casualties } \\
\text { (n.) }\end{array}$ & $\begin{array}{l}\text { Estimated total damage } \\
\text { (million of Euros) }\end{array}$ & $\begin{array}{c}\text { Estimated total damage } \\
(\%)\end{array}$ \\
\hline $16-22$ & Oct 1951 & Calabria - Sardegna - Sicilia & 110 & 15.49 & 0.2791 \\
\hline $8-12$ & Nov 1951 & $\begin{array}{c}\text { Emilia Romagna - Liguria } \\
\text { Lombardia - Piemonte - Veneto }\end{array}$ & 100 & 206.58 & 3.7216 \\
\hline $20-2$ & Dec-Jan 1972-1973 & $\begin{array}{c}\text { Abruzzo - Basilicata - Calabria } \\
\text { Campania - Marche - Molise - Sicilia }\end{array}$ & 20 & 464.81 & 1.1218 \\
\hline 5 & Nov 1976 & Sicilia & 18 & 51.65 & 0.0571 \\
\hline $3-6$ & Nov 1994 & Piemonte & 64 & 2840.51 & 0.3326 \\
\hline $4-6$ & May 1998 & Campania & 160 & 550.00 & 0,0513 \\
\hline 15-18 & Oct 2003 & Sicilia & 1 & 121.40 & 0,0093 \\
\hline $11-13$ & Dec 2003 & Calabria & 1 & 107.76 & 0,0083 \\
\hline
\end{tabular}

In 2002-2003, a new catalogue of historical floods, which considers also flood consequences on the Italian population, was assembled by Guzzetti et al. (2005). It was compiled employing the same sources of information used for the database of landslides of Guzzetti (2000), a revised version of the AVI project archive, the work of Catenacci (1992), reports describing individual meteorological or hydrological events that produced floods and landslides, and reports describing the occurrence of historical inundations in either selected areas, individual regions or river basins. Additional information was taken by internet web sites.

The historical flood catalogue covers the 686-year period, from 1317 to 2002. The authors of this database encountered our same difficulties in finding an exact number of casualties in the oldest reports, since they often give only a qualitative description of the number of fatalities (i.e., a few, many, hundreds, thousands). They also noticed that in general, the number of fatalities caused by landslides is more precise than the number of deaths and missing persons produced by inundations. The oldest reports and the repertoires of floods and landslides contained relatively little information on human consequences. Sometimes, they described flood effects in terms of total or partial destruction of villages and towns, without reporting any information on injuries and deaths, also if it is extremely probable that casualties did occur.

\section{The APAT approach for flood databases}

Even if AVI files have been the basis for the two APAT databases (the historical and updating archives), both devoted to the most relevant floods, aims and criteria for data selection have been reconsidered, enlarging and updating those sources formerly exploited. In 2004, these databases were published by APAT in the Italian Environmental Data Yearbook, in the chapter titled "Natural Hazards".

The first database, the historical archive, covers the time period from 1951 to 2003 (see Table 1); whereas the second one, the updating archive, contains data related to observed flood events from 2003 on. The choice of starting the flood historical archive from 1951, that is after the II World War, was driven by the difficulty of finding detailed and reliable documentation concerning economic damages and casualties for years before 1951 . 


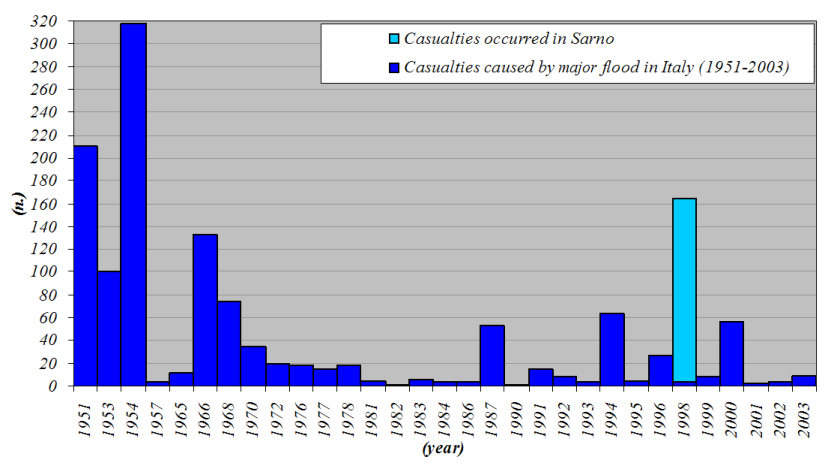

Fig. 1. Casualties caused by major flood events in Italy (19512003), also with respect to the Sarno flood event (see in Table 1 the Campania event in May 1998).

Information reported in both archives has been retrieved from technical reports and/or documentation edited by APAT itself (SIMN, 1951-1984), ARPAs and other public bodies, institutions, ministries and chronicle sources (Benedini and Gisotti, 1999; Centro studi per la flora mediterranea, 1984; Crescenti, 2003; Esposito et al., 2002; ISTAT, 1951-2003; Ministero dei Lavori Pubblici, 1969; The OFDA/CRED, 2003). Data were stored into the two archive using the Microsoft Excel software.

For what concerns the economic losses, they were estimated considering funds necessary for restoration. In other words, they were tallied upon the losses due to partial or total destruction of buildings, infrastructures and engineering works; interruption of economic activities and public services; etc.

3.1 Type of information stored in the APAT historical archive

Data collected into the historical archive are related to single events rather than to the struck sites. Only flood events, having either generated a casualty at least or economic damages higher than $0.001 \%$ of Gross Domestic Product (GDP), have been considered relevant for the database and defined as major floods (see Figs. 1 and 2).

In particular, the information stored consists of:

- duration of a certain flood event;

- Italian regions struck by the flood;

- number of casualties (Fig. 1);

- estimated economic total damage (per million of Euros; Fig. 2).

Furthermore, economic damages have been also updated in relation with GDP (see last column in Table 1), in order to permit an intercomparison among economic losses caused by flood events occurred in different historical periods and in different economic conditions.

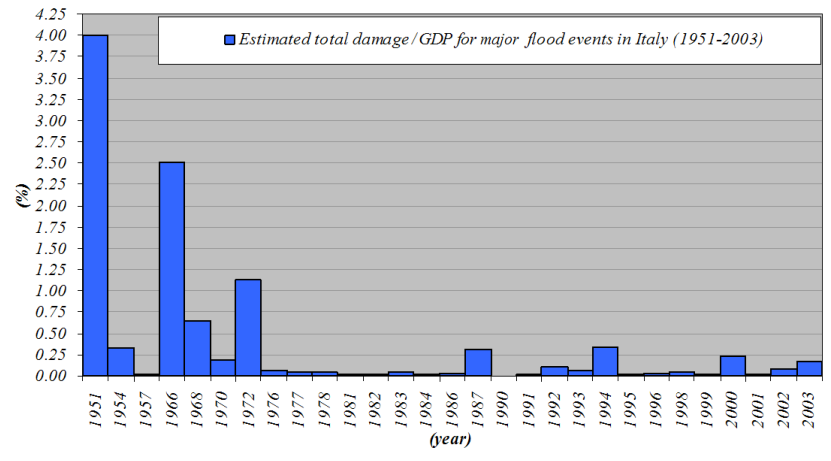

Fig. 2. Estimated total damage updated in relation with the GDP, for the major flood events in Italy (1951-2003).

3.2 Type of information stored in the APAT updating archive

Starting from 2003, APAT has been carrying out a systematic monitoring of flooding events (see Fig. 3 and Tables 2 and 3) which, in comparison with the historical archive, have been characterized through further data related to hydrological aspects, effects on soil and the consequent legislative measures. In this archive, only flood events, having caused a declaration of the state of emergency through a decree of the President of the Council of Ministers (DPCM Emergenza, see Table 3), have been considered as major floods.

As for the examined hydrological features, the following information has been reported:

- hydrographic basins affected by floods;

- total duration of precipitation;

- the rain gauge which has recorded the maximum total rainfall in the lapse of $24 \mathrm{~h}$;

- the maximum total rainfall value in $24 \mathrm{~h}$ (observed by the hydro-meteorological network of the real-time monitoring system).

As for flood consequences, besides the fields already included in historical archive, information has been inserted about all types of upheaval caused by precipitation, the number of people involved, the loss of structures and the emergency legislative measures. Moreover, it was decided to include also a list of Italian municipalities struck by floods (see Fig. 3).

\section{Results and conclusions}

Fifty-five flood events have been collected into the historical archive. As expected, Piemonte, Liguria, Sicilia, Toscana, Lombardia, Calabria and Campania result to be the Italian regions more often struck by major floods. Overall, the events collected in this database caused 1394 casualties, half of 
Table 2. Italian major floods in 2003 with indication of struck hydrological basins. For each flood event, regional location, duration (time period and hours) and the maximum 24-h accumulated precipitation (with rain gauge name) are also reported. Information is not totally available for the Abruzzo, Campania and Sicilia events.

\begin{tabular}{|c|c|c|c|c|c|}
\hline Region & Hydrographic basin & Flood time period & $\begin{array}{l}\text { Total duration } \\
\text { (h) }\end{array}$ & $\begin{array}{l}\text { Max precipitation } \\
\quad(\mathrm{mm} / 24 \mathrm{~h})\end{array}$ & $\begin{array}{l}\text { Rain gauge } \\
\text { name }\end{array}$ \\
\hline Molise & Biferno - Fortore - Trigno & 23-26 Jan 2003 & 84 & 187.8 & Casacalenda \\
\hline Abruzzo & Pescara - Sangro - Trigno & 23-26 Jan 2003 & 72 & 354.0 & - \\
\hline Puglia & $\begin{array}{c}\text { Candelaro - Carapellotto - Celone } \\
\text { Cervaro - Fortore - Sannoro - Triolo }\end{array}$ & 24-26 Jan. 2003 & - & - & - \\
\hline Campania & Calore - Miscano - Ufita - Volturno & 24-26 Jan 2003 & 108 & 77.6 & Rotondi \\
\hline Friuli & Fella (Tagliamento) & 29-30 Aug 2003 & 21 & 396.2 & Pontebba \\
\hline Puglia & Lato - Tara & 8 Sep 2003 & 9 & 244.2 & Castellaneta \\
\hline Campania & Irno - Sarno & 9 Sep 2003 & 4 & 87.0 & Capodimonte \\
\hline Sicilia & Anapo & 17-18 Sep 2003 & 120 & $\begin{array}{l}234.0 \\
398,4\end{array}$ & $\begin{array}{c}\text { Melilli-Siracusa } \\
\text { Siracusa }\end{array}$ \\
\hline Toscana & Carrione & 23-24 Sep 2003 & 20 & 332.6 & Orto di Donna \\
\hline Sicilia & Salso & $15-18$ Oct 2003 & - & 109.0 & Aidone \\
\hline Calabria & Ancinale - Mesima - Petrace & 11-13 Dec 2003 & 36 & 320.2 & Gambarie \\
\hline
\end{tabular}

which occurred during the time period from 1951-1970. Besides, taking into account the entire analyzed period (19512003), the study has pointed out that almost $50 \%$ of examined floods caused more than 5 casualties and almost $10 \%$ more than 100 .

These data confirm the considerable social impact caused, at national level, by these natural phenomena. Apart from the event occurred in Sarno on May 1998 (see Table 1) where casualties were induced more through from a debris flow, the data evaluation has shown a general decrease of casualties and damages caused by floods during the time considered. However a trend cannot be defined, since data are not homogeneous and it is necessary to compare damages and casualties caused by events of the similar intensity hitting the same areas, in order to carry out a meaningful estimation.

Moreover, the soil impact showing the destructive power of floods cannot always be correlated with their hydro-meteorological intensity. In fact from the hydrometeorological point of view the relevance of an event is valuable on the basis of completely natural factors (duration, rainfall intensity, river discharge, etc.).

On the other side, soil effects and damages severity is connected to factors like land use, processes dynamics and to the eventual presence, efficiency and functionality of protection works. Of course it is clear that generally a wider territorial distribution of settlements causes worse damages under the

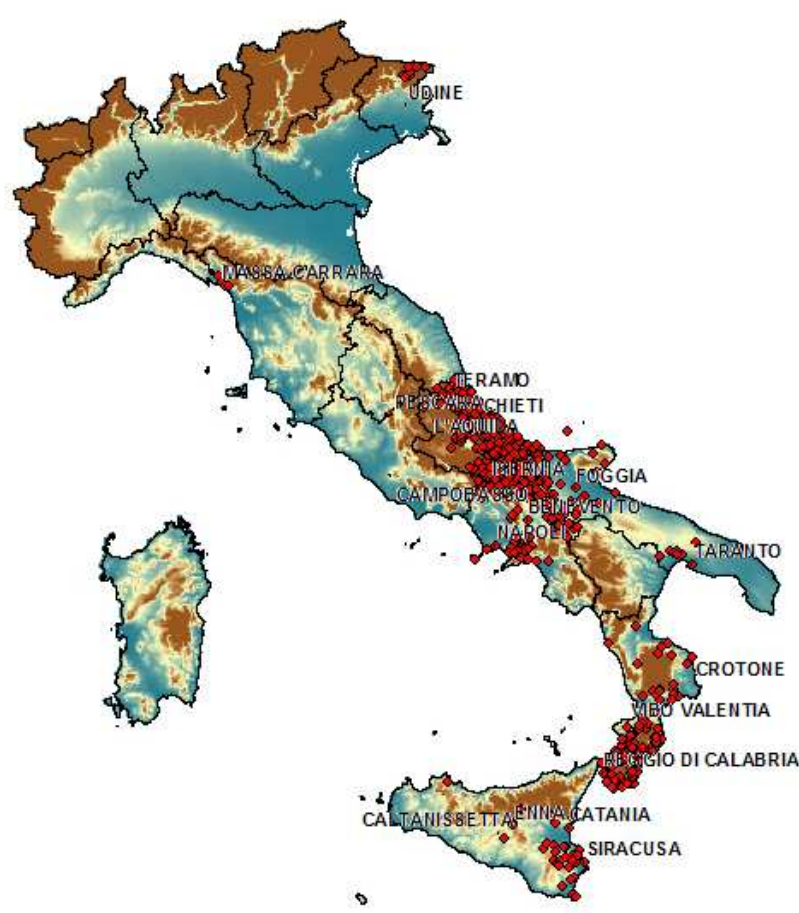

Fig. 3. Italian municipalities struck by floods in 2003 . 
Table 3. Soil impact for the flood events reported in Table 2. Estimated funds for restoration and Italian legislative measures are also indicated. Information is not completely available. The costal, hydraulic and landslide disruption are indicated with $\mathrm{C}, \mathrm{H}$ and $\mathrm{L}$, respectively.

\begin{tabular}{|c|c|c|c|c|c|c|}
\hline Region & Flood time period & $\begin{array}{l}\text { Type of } \\
\text { disruption }\end{array}$ & $\begin{array}{l}\text { Involved people } \\
\text { (n.) }\end{array}$ & $\begin{array}{l}\text { Casualties } \\
\text { (n.) }\end{array}$ & $\begin{array}{l}\text { Est. restoration funds } \\
\text { (million of Euros) }\end{array}$ & $\begin{array}{l}\text { Legislative measures } \\
\text { (with date) }\end{array}$ \\
\hline Molise & 23-26 Jan 2003 & $\mathrm{H}, \mathrm{L}$ & 190000 & 1 & 140 & $\begin{array}{l}\text { DPCM Emergenza }-31 / 01 / 2003 \\
\text { DPCM Emergenza - 05/03/2004 } \\
\text { Ordinanza n. } 3268-12 / 03 / 2003\end{array}$ \\
\hline Abruzzo & 23-26 Jan 2003 & $\mathrm{H}, \mathrm{L}$ & 40000 & - & 130 & $\begin{array}{l}\text { DPCM Emergenza - 31/01/2003 } \\
\text { DPCM Emergenza - 05/03/2004 } \\
\text { Ordinanza } \mathrm{n} .3281-18 / 04 / 2003\end{array}$ \\
\hline Puglia & 24-26 Jan 2003 & $\mathrm{H}, \mathrm{L}$ & 40000 & - & 450 & $\begin{array}{l}\text { DPCM Emergenza }-31 / 01 / 2003 \\
\text { DPCM Emergenza - 05/03/2004 } \\
\text { Ordinanza } \mathrm{n} .3280-18 / 04 / 2003\end{array}$ \\
\hline Campania & 24-26 Jan 2003 & $\mathrm{H}, \mathrm{L}$ & - & - & 90 & $\begin{array}{l}\text { DPCM Emergenza }-31 / 01 / 2003 \\
\text { DPCM Emergenza }-05 / 03 / 2004 \\
\text { Ordinanza } \mathrm{n} .3322-23 / 10 / 2003\end{array}$ \\
\hline Friuli & 29-30 Aug 2003 & $\mathrm{H}, \mathrm{L}$ & 5000 & 2 & 522 & $\begin{array}{l}\text { DPCM Emergenza - 05/09/2003 } \\
\text { Ordinanza } \text { n. } 3309-11 / 09 / 2003 \\
\text { Ordinanza } \text { n. } 3339-20 / 02 / 2004\end{array}$ \\
\hline Puglia & 8 Sep 2003 & $\mathrm{H}$ & 4900 & 2 & 313 & $\begin{array}{l}\text { DPCM Emergenza - 12/09/2003 } \\
\text { Ordinanza n. } 3323-05 / 11 / 2003\end{array}$ \\
\hline Campania & 9 Sep 2003 & $\mathrm{H}$ & - & 1 & 10 & DPCM Emergenza - 03/10/2003 \\
\hline Sicilia & 17-18 Sep 2003 & $\mathrm{H}, \mathrm{L}$ & 30000 & - & 100 & $\begin{array}{l}\text { DPCM Emergenza - 19/09/2003 } \\
\text { Ordinanza n. } 3320-23 / 10 / 2003\end{array}$ \\
\hline Toscana & 23-24 Sep 2003 & $\mathrm{H}, \mathrm{L}$ & 10000 & 1 & 200 & $\begin{array}{l}\text { DPCM Emergenza - 29/09/2003 } \\
\text { Ordinanza n. } 3325-07 / 11 / 2003\end{array}$ \\
\hline Sicilia & 15-18 Oct 2003 & $\mathrm{H}, \mathrm{L}$ & - & 1 & 121.4 & $\begin{array}{l}\text { DPCM Emergenza }-07 / 11 / 2003 \\
\text { Ordinanza n. } 3340-20 / 02 / 2004\end{array}$ \\
\hline Calabria & 11-13 Dec 2003 & $\mathrm{C}, \mathrm{H}, \mathrm{L}$ & - & 1 & 107.76 & DPCM Emergenza - 25/03/2004 \\
\hline
\end{tabular}

same hydrological conditions. In addition a better attention to soil protection and an improvement of monitoring and alert systems, entail, under the same event intensity, a decrease of casualties or a better infrastructure safeguard.

Therefore, it is not fully possible to state that the positive trend shown by diagrams, except for Sarno (see Fig. 1) is mainly due to better developed soil defence systems or can be originated by a natural drop of the destructive power of these phenomena.

For the updating archive, it is worth noting the strong difference between the funds requested by local authorities for restoration and the funds actually allocated by regions or the central government through legislative measures (see Ordinanza in Table 3).
This archive could be improved adding much more information for hydrological analysis (e.g., water depth, river discharge, etc.), soil impact evaluation of flood events (e.g., areal extension of inundations) and verification of the all adopted measures. The analysis of all these aspects will lead to a more objective and complete determination of the territory response changing during passing time in case of extreme events. Furthermore, the filled information will be successfully utilized in order to decide which interventions are to be preferred for an effective mitigation of impacts.

Acknowledgement. The authors thank E. Giusta (APAT) for the support supplied.

Edited by: V. Kotroni and K. Lagouvardos Reviewed by: anonymous referee 


\section{References}

Benedini, M. and Gisotti G.: Il dissesto Idrogeologico, NIS, la Nuova Italia Scientifica, II edizione, in Italian, 1999.

Catenacci, V.: Il dissesto geologico e geoambientale in Italia dal dopoguerra al 1990. Memorie descrittive della Carta Geologica d'Italia, 47, 1-301, in Italian, 1992.

Centro studi per la flora mediterranea (Borgo Val di Taro): L'alluvione del fiume Taro nel novembre 1982, Atti del Convegno sul dissesto territoriale del novembre 1982 nelle valli del Taro e del Ceno, in Italian, 1984.

Crescenti, U.: Il dissesto idrogeologico in Italia, Scienza e Tecnica, ANNO LXVI, N. 393, in Italian, 2003.

Delitala, A. M. S.: Perception of intense precipitation events by public opinion, Nat. Hazards Earth Syst. Sci., 5, 499-503, 2005.

Esposito, E., Porfido, S., Violante, C., and Alaia, F.: Disaster induced by historical floods in a selected coastal area (Southern Italy), Phefra (Paleofloods, Historical Data \& Climatic Variability: Application in Flood Risk Assessment), International Workshop, Barcellona, Spain, 143-148, October 2002.

Granger, K.: Hazards and risk concepts, in: Natural hazards and the risks they pose to South-East Queensland, edited by: Granger, K. and Hayne, M., in conjuction with the Bureau of Meteorology, pp. 1.1-1.13, Australian Geological Survey Organisation, 2000.
Guzzetti, F.: Lanslide fatalities and evaluation of landslide risk in Italy, Eng. Geol., 58, 89-107, 2000.

Guzzetti, F. and Tonelli, G.: SICI: an information system on historical landslides and floods in Italy. Nat. Hazards Earth Syst. Sci., 4, 213-232, 2004.

Guzzetti. F., Stark. C. P., and Salvati, P.: Evaluation of flood and landslide risk to the population of Italy, Environ. Manage., 36, 15-36, 2005.

ISTAT: Conti economici nazionali, in Italian, 1951-2003.

Messner, F. and Meyer, V.: Flood damage, vulnerability and risk perception - challenges for flood damage research, UFZ LeipzipHalle, UFZ-Diskussionspapiere, 2005.

Ministero dei Lavori Pubblici: L'evento alluvionale del novembre 1966, Commissione Interministeriale per lo studio della sistemazione idraulica e della difesa del suolo, in Italian, 1969.

Plate, E. J.: Flood risk and flood management, J. Hydrol., 267, 2$11,2002$.

Plattner, T.: Modelling public risk evaluation of natural hazards: a conceptual approach, Nat. Hazards Earth Syst. Sci., 5, 357-366, 2005.

Servizio Idrografico e Mareografico Nazionale: Annali Idrologici, in Italian, 1951-1984.

The OFDA/CRED: EM-DAT (Emergency Disasters Data Base), Universit catholique de Louvain, Brussels, Belgium, 2003. 